\title{
Harmful Algal Blooms Associated with Volcanic Eruptions in Indonesia and Philippines for Korean Fishery Damage
}

\author{
Tai-Jin Kim \\ Department of Chemical Engineering, University of Suwon, Hwaseong City, South Korea \\ Email: tjkim@suwon.ac.kr
}

How to cite this paper: Kim, T.-J. (2020) Harmful Algal Blooms Associated with Volcanic Eruptions in Indonesia and Philippines for Korean Fishery Damage. $A d$ vances in Bioscience and Biotechnology, 11, 217-236.

https://doi.org/10.4236/abb.2020.115017

Received: December 18, 2019

Accepted: May 26, 2020

Published: May 29, 2020

Copyright (c) 2020 by author(s) and Scientific Research Publishing Inc. This work is licensed under the Creative Commons Attribution International License (CC BY 4.0).

http://creativecommons.org/licenses/by/4.0/

\begin{abstract}
Harmful Algal Blooms (HAB) were analyzed to trace the outbreak of dinoflagellate Cochlonidium polykrikoides on the Korean coast from 1993 to 2019 along with relationship to volcanic eruptions. Parameters associated with blooms and fishery damage were sunspot number, El Niño/La Niña events, Kuroshio Current, and volcanic eruptions in the South China Sea including Indonesia and the Philippines. $\mathrm{HAB}$ development was halted in seawater due to the sulfur compounds $\left(\mathrm{H}_{2} \mathrm{~S}, \mathrm{SO}_{2}\right.$, sulfates) from volcanic eruptions inducing the deficiency of the dissolved iron $(\mathrm{Fe})$ in the seawater. Cochlonidium polykrikoides blooms could be predicted by the minimal sunspot number during La Niña event or weak volcanic eruptions in Indonesia and the Philippines. On line monitoring of $\mathrm{HAB}$ was suggested using a prototype detector of Cochlonidium polykrikoides at wavelength of $300 \mathrm{~nm}$ with the concentration linearity $\left(\mathrm{R}^{2}=0.9972\right)$ between 1000 and $6000 \mathrm{cells} / \mathrm{ml}$. HABs on the Korean coast were negligible when there were volcanic eruptions in either Indonesia or Philippines from May to August. Fishery damage was linearly proportional $\left(\mathrm{R}^{2}=0.2986\right)$ to the maximal concentration of HAB while 5000 cells $/ \mathrm{ml}$ was the minimal concentration of $\mathrm{HAB}$ with high linearity $\left(\mathrm{R}^{2}=\right.$ 0.7629), caused by old cysts of Cochlonidium polykrikoides on the Korean coast rather than the fresh ones carried by the Kuroshio Current from the Philippines. Fishery damage was reversely proportional to the number of sunspots; the maximal number of sunspots induced frequent volcanic eruption in Indonesia and the Philippines for retardation of HAB with less fishery damage in Korea while the minimal number of sunspots caused less volcanic eruptions for thereby enhancing $\mathrm{HAB}$ resulting in more fishery damage. It was proposed that a yellow LED be used at $590 \mathrm{~nm}$ as a photochemical expellent as well as $\mathrm{H}_{2} \mathrm{~S}$ gas bubbling at a 0.5 meter depth on the surface of the fish cage to inactivate chemically Cochlonidium polykrikoides due to the defi-
\end{abstract}


ciency of essential iron in the seawater. In addition, the physical method of blanketing the cage cloth with smaller pore diameter than that of HAB was used for prevention of Cochlonidium polykrikoides penetrating into the fish cage.

\section{Keywords}

Harmful Algal Blooms, Volcanic Eruption, Indonesia, Philippines, Korean Fishery Damage

\section{Introduction}

Harmful algae have been the subject of scientific and societal interest for centuries. There are Harmful Algal Blooms (HAB) in seawater. This is because blooms of toxic dinoflagellates, which are known as "red tides", cause a variety of deleterious effects on aquatic ecosystems. These include negative effects such as beach fouling, oxygen deficiency, clogging of fish gills, or poisoning of various organisms [1]. Red tides of Chattonella have killed fish on a large scale which has been recorded in Japan, China, USA (Florida), and South Australia while having done the same in Korenia brevis in Florida in 2018 [2]. Chattonella spp. has also been observed in Southeast Asia, New Zealand, Brazil and Europe (North Sea). Red tides of $H$. akashiwo accompanied by the death of salmon and yellowtail have occurred in Japan, Canada (British Columbia), New Zealand, Chile, and Scotland. The mechanism by which Chattonella spp. kills fish remains unclear, but suffocation due to gill tissue damage was the ultimate cause of fish death [3]. Kim [4] proposed that $\mathrm{HAB}$ occur only if the environmental factors such as light, nutrients, calm water surface layer, temperature, and $\mathrm{pH}$ could all simultaneously match with the requirements of the mineral ions supplied by the Asian dust as enzymatic cofactors for the rapid bio-synthesis of the macromolecules during $\mathrm{HAB}$ within a limited area. Kim [5] also showed the prevention of HAB by control of growth parameters including the iron $(\mathrm{Fe})$ in global aeolian dust and water as the key initiator for $\mathrm{HAB}$ while sulfur compounds $(\mathrm{S})\left(\mathrm{S}, \mathrm{SO}_{2}, \mathrm{SO}_{3}\right.$, $\mathrm{H}_{2} \mathrm{~S}, \mathrm{H}_{2} \mathrm{SO}_{4}$, sulfates) from $\mathrm{SO}_{2}$ plumes during volcanic eruptions and volcanic ashes deplete $\mathrm{Fe}$ in the forms of iron sulfides $\left(\mathrm{FeS} / \mathrm{FeS}_{2}\right)$. Since 1880, El Niño events have occurred roughly every $2-7$ years with no clear periodicity while the sunspot number changes through an average cycle of 11 years with 14 months standard deviation [6]. Higher Sea Surface Temperature (SST) anomalies were observed in El Niño years while cooler anomalies were seen during La Niña years. During El Niño years, the ocean becomes noticeably warmer and the air pressure is high with rainfall and flooding. El Niño years have a harmful effect on fish, birds, and any other species that live in or near the Pacific Ocean. La Niña is essentially the anti-El Niño. Instead of warm seawater and high air pressure, the seawater is cold and air pressure is low with drought conditions and cold weather. La Niña years often cause heavy snowfalls even in parts of the 
world far away from the Pacific [7]. Cochlonidium polykrikoides have caused great economic losses in the seawater of South Korea. Predicting the outbreak of Cochlonidium polykrikoides is thus important in minimizing fishery losses [8].

The purpose of the present study is to predict in advance the year of the high fishery damage in South Korea by Cochlonidium polykrikoides blooms associated with minimal sunspot number, La Niña and weak volcanic eruptions in Indonesia or Philippines.

\section{Experiment}

\subsection{Distribution of Cochlonidium polykrikoides Population from Indonesia and the Philippines to Korea and Japan}

Cochlonidium polykrikoides cultured in Indonesia have to pass Banda Sea, Celebes Sea and South China Sea to reach Luzon Island in the Philippines. The Kuroshio Current carries Cochlonidium polykrikoides through major volcanoes in Indonesia (Dempo, Dieng, Slamet, Kaba, Inielika, Papandayan, Ruang, Lewotobi, Gamalama, Marapi, Kerinci, Tengger, Rinjani, Awu, Talang, Ibu, Egon, Gamkonora, Soputan, Karangetang, Merapi, Lokon-Empung, Kelud, Sangeang, Raung, Agung, Krakatau, Sinabung), while there are volcanic eruptions in the Philippines (Bulusan, Kanlaon, Mayon, Taal, Pinatubo) and submarine volcanoes (Didicas, Camiguin de Babuyanes, Iraya, Pangasun, Babuyan Claro). Since submarine volcanic eruptions release sulfur compounds $\left(\mathrm{S}, \mathrm{SO}_{2}, \mathrm{H}_{2} \mathrm{~S}, \mathrm{H}_{2} \mathrm{SO}_{4}\right.$, sulfates) and toxic chemicals ( $\mathrm{HF}, \mathrm{HCl}$ ) directly into seawater with Cochlonidium polykrikoides, such a volcanic eruption can kill Cochlonidium polykrikoides. Furthermore $\mathrm{SO}_{2}$ plume from main volcanic eruption can be deposited on the surface of seawater to kill Cochlonidium polykrikoides at a daytime residence depth of 0.5 to 4 meters [10] from the sea surface. The essential nutrient of iron for the growth of phytoplankton is combined with sulfur compounds to retard the growth of algae [5]. It is thus possible that volcanic eruptions either in Indonesia or in the Philippines may reduce Cochlonidium polykrikoides blooms in South Korea.

\subsection{Passage of Cochlonidium polykrikoides from Indonesia to South Korea}

Indonesia is a good reservoir for the growth of Cochlonidium polykrikoides, as shown in Figure 1, due to the following reasons [5]:

1) Many volcanoes (127) to supply nutrients during volcanic eruptions.

2) Strong solar radiation energy at $300 \mathrm{~nm}$ (Figure 4) near the Equator.

3) Many islands $(18,000)$ for the growth at each seashore.

4) Indonesian Throughflow during monsoon (June, July, August) with fast currents of 8 knots $(4.1 \mathrm{~m} / \mathrm{s})$ for mixing food-webs.

5) Wind driven supply of enriched iron $(\mathrm{Fe})(7 \%-18 \%)$ desert dust from Australia for the growth of HAB.

Therefore, Indonesia is a good starting point for the warm Kuroshio Current 


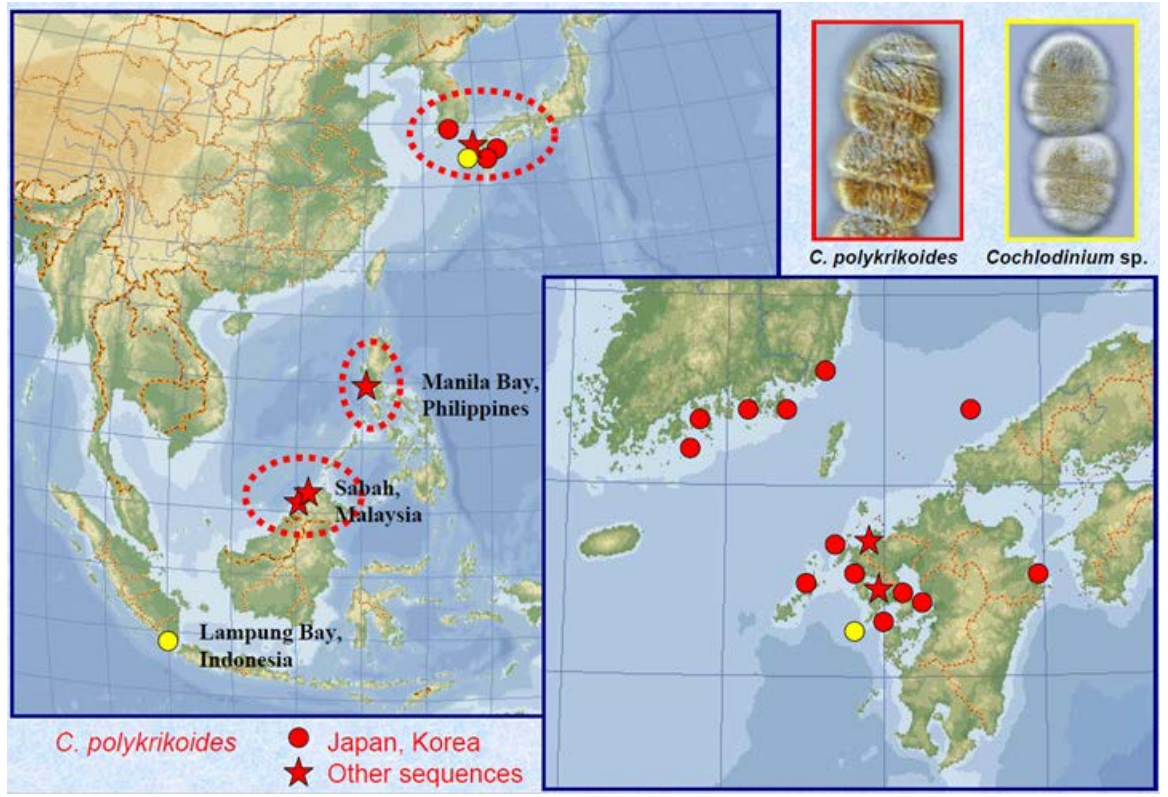

Figure 1. Distribution of C. polykrikoides population from Indonesia and the Philippines to Korea and Japan [9].

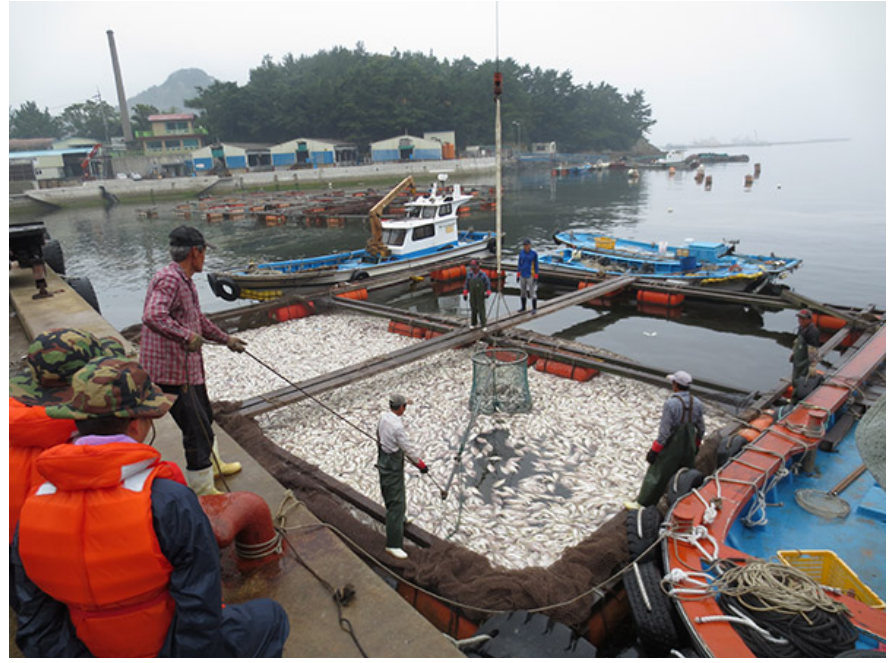

Figure 2. Fishery damage by harmful algal blooms at Tongyoung City of South Korea in July of 2013.

$(1.0-2.0 \mathrm{~m} / \mathrm{s})$ to carry Cochlonidium polykrikoides to fish farmers in Korea and Japan during summer, as shown in Figure 1 with fishery damage in Figure 2.

The Kuroshio is a warm northeasterly ocean current off the coast of Japan. Kuroshio means "the black stream" in Japanese, named after the deep ultramarine color of the high salinity water, which is found flowing north of the current's axis, as shown in Figure 3.

The Kuroshio originates from the greater part of North Equatorial current, which divides east of the Philippines. The Kuroshio is the current running from Formosa to about 35 degrees $\mathrm{N}$ latitude. It continues directly as a warm current known as the Kuroshio Extension; from there it continues as the North Pacific 


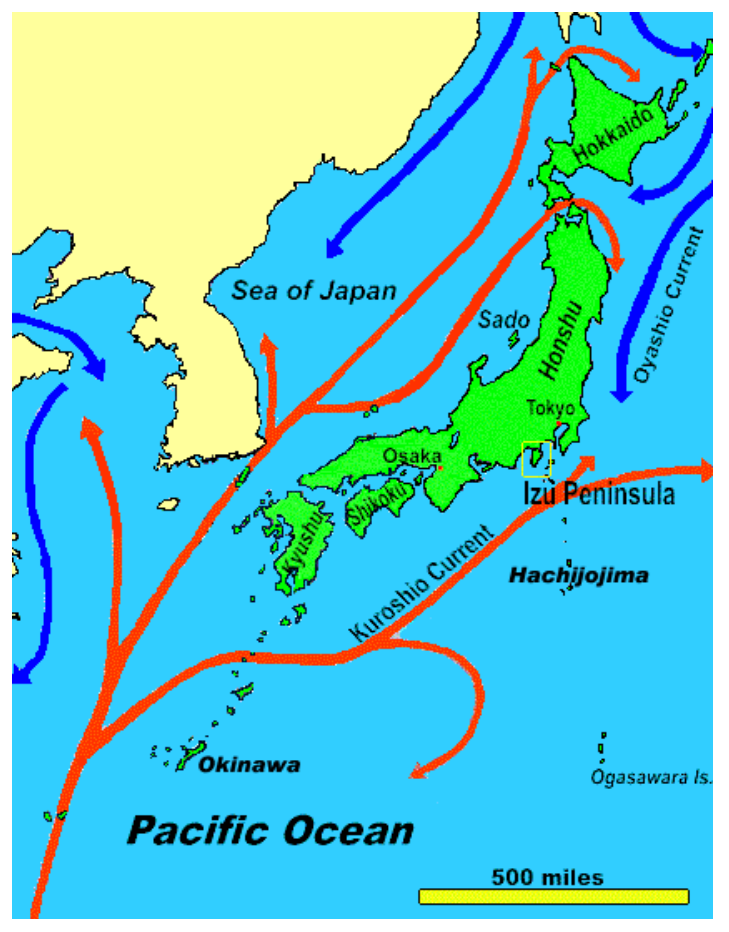

Figure 3. Kuroshio Current in the Pacific Ocean [11].

current along the western edge of the Pacific, between the Philippines and the east coast of Japan.

Kuroshio is a fast ocean current ( 2 to 4 knots) that reaches Korea in 15 to 30 days. The current carries some 50 million tons of seawater every second past Japan's southeast coast. The Kuroshio Current plays a vital role in the circulation of the North Pacific Ocean. The current transports great volumes of water capable of carrying large amounts of heat. The heat, which is carried north by this flow, has an effect on the climate of the adjacent land areas. Water temperature offshore strongly influences cloud cover and rainfall. On the southern coast of Alaska, the effect of the Kuroshio Extension creates a somewhat more temperate climate.

\subsection{Schematic Determination of Real-Time Concentration for Cochlonidium polykrikoides}

The scanning data $(250-350 \mathrm{~nm})$ of optical density for Cochlonidium polykrikoides [6] at a cell concentration of 1000, 3000, and $6000 \mathrm{cells} / \mathrm{ml}$ (Figure 4(a)) [12], were plotted to obtain the minimal first derivatives. This method proposed $300 \mathrm{~nm}$ as the optimal optical density for the measurement of Cochlonidium polykrikoides, as shown in Figure 4(b). Figure 4(c) showed that the real-time cell concentrations of Cochlonium polykrikoides were linearly $\left(\mathrm{R}^{2}=0.9972\right)$ proportional to the optical densities at $300 \mathrm{~nm}$, which could be caused by its preference for ultraviolet band with high energy in accordance with the Einstein-Planck relation. It was thus possible to determine the on-line cell concentration of Cochlonidium polykrikoides at $300 \mathrm{~nm}$ instead of the present tedious 

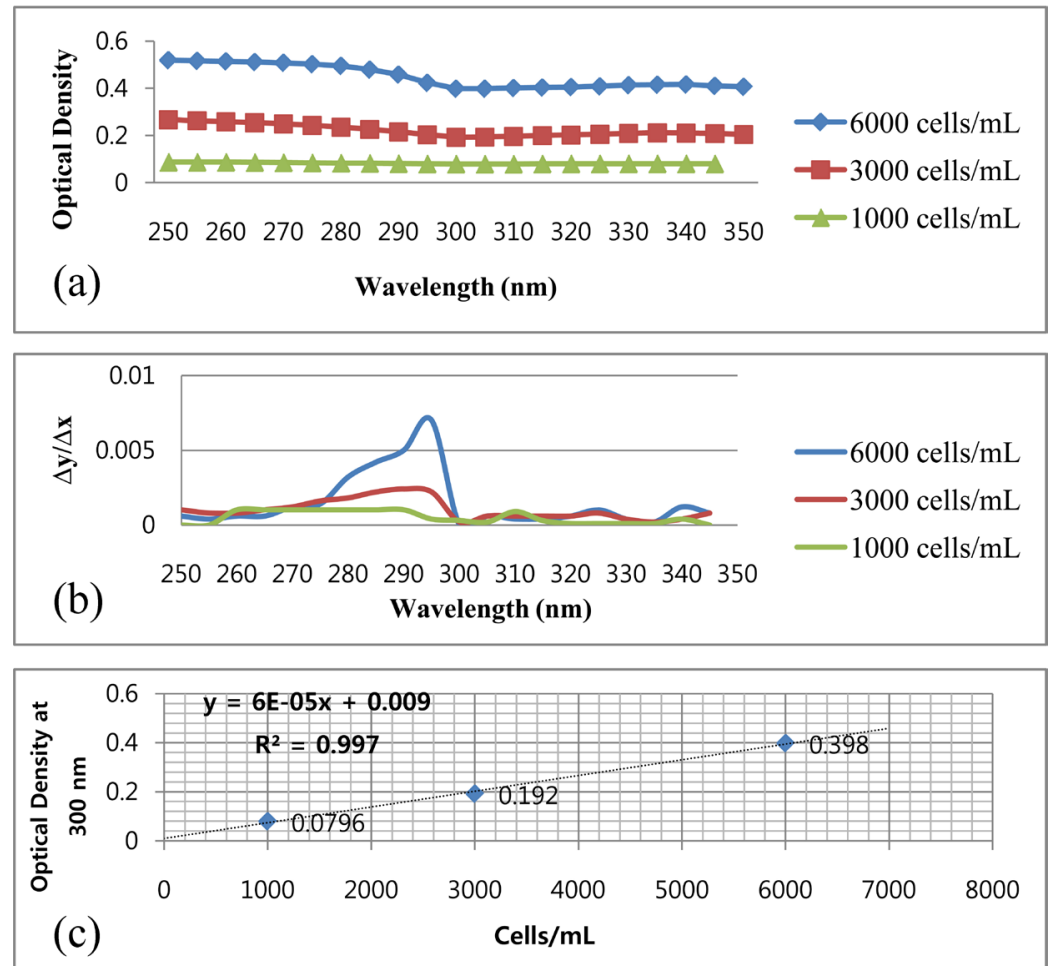

Figure 4. (a) Data (250 - $350 \mathrm{~nm}$ ) for Cochlonidium polykrikoides [12]. (b) The optimal optical density for the measurement of Cochlonium polykrikoides was determined to be $300 \mathrm{~nm}$ based on the minimal first derivatives of individual scanning at 1000, 3000, 6000 cells/ml. (c) Distribution of the cell concentrations of Cochlonidium polykrikoides at $1000,3000,6000$ cells $/ \mathrm{ml}$ showed the high linearity $\left(\mathrm{R}^{2}=0.9972\right)$ with the optimal optical density at $300 \mathrm{~nm}$.

method of cell number counting by microscope after off-line sampling, requiring at least a week to be analyzed for fishery farmers.

\subsection{Mass Balance of Cochlonidium polykrikoides in the South China Sea}

The accumulation rates of Cochlonidium polykrikoides ("Cp") in the South China Sea, $\left(\frac{\mathrm{d} C p}{\mathrm{~d} t}\right)$, is given by:

$$
\frac{\mathrm{d} C p}{\mathrm{~d} t}=(\dot{C} p)_{\text {in }}-(\dot{C} p)_{\text {out }}+(\dot{C} p)_{g e n}-(\dot{C} p)_{c o n}-(\dot{C} p)_{r x n}
$$

where

$(\dot{C} p)_{i n}=$ the input rate of $\mathrm{Cp}\left(\right.$ cells $\left.\cdot \mathrm{ml}^{-1} \cdot \mathrm{d}^{-1}\right)$ from Indonesia and the Philippines to Korea,

$(\dot{C} p)_{\text {out }}=$ the output rate of $\mathrm{Cp}$ to Japan,

$(\dot{C} p)_{\text {gen }}=$ the generation rate of $\mathrm{Cp}$ within the Korean coast,

$(\dot{C} p)_{c o n}=$ the consumption rate of $\mathrm{Cp}$ by phytoplankton assimilation,

$(\dot{C} p)_{r x n}=$ reaction rate of $\mathrm{Cp}$ with volcanic $\mathrm{S}$ compounds as sedimentary FeS 
and $\mathrm{FeS}_{2}$.

Kim et al. [13] showed that the volcanic eruptions producing $\mathrm{S}$ compounds ( $\mathrm{S}$, $\mathrm{SO}_{2}, \mathrm{H}_{2} \mathrm{~S}, \mathrm{H}_{2} \mathrm{SO}_{4}$, sulfates). Fe compounds $\left(\mathrm{Fe}_{2} \mathrm{O}_{3}, \mathrm{Fe}_{3} \mathrm{O}_{4}, \mathrm{FeCl}_{2}, \mathrm{FeF}_{2}, \mathrm{FeF}_{3}, \mathrm{FeS}\right.$, $\mathrm{FeS}_{2}, \mathrm{FeSO}_{4}$ and $\left.\mathrm{Fe}_{2}\left(\mathrm{SO}_{4}\right)_{3}\right)$ by Schrope [14] induce the chemical product of $\mathrm{FeS}$ and $\mathrm{FeS}_{2}$ for Fe-limited low-chlorophyll. It is therefore expected that there will be a low concentration of Cochlonidium polykrikoides, after frequent volcanic eruptions in Indonesia or the Philippines, carried by Kuroshio Current to reach the Korean coast. Since the strong volcanic eruption in the Galapagos Hot Spot was linearly correlated $\left(\mathrm{R}^{2}=0.9939\right)$ with El Niño events [6], it is expected that there will be weak volcanic eruption during La Niña event.

\section{Results and Discussion}

\subsection{Determination of Real-Time Cell Concentration of Cochlonidium polykrikoides}

No one has yet proposed a real-time measurement device for Cochlonidium polykrikoides, which may allow the early warning of using a smart phone system so long as a portable detector is available at $300 \mathrm{~nm}$, as shown in Figure 5 and Figure 6.

\subsection{Prevention of Harmful Algal Blooms by Volcanic Sulfur Compounds}

Volcanic gases are commonly composed of $\mathrm{H}_{2} \mathrm{O}(37 \%-97.1 \%), \mathrm{CO}_{2}, \mathrm{SO}_{2}(0.50 \%$ - $11.8 \%), \mathrm{H}_{2}, \mathrm{CO}, \mathrm{H}_{2} \mathrm{~S}(0.04 \%-0.68 \%), \mathrm{HCl}$, and $\mathrm{HF}$ during volcanic eruptions [14]. Volcanic ash has an iron complex in the forms of $\mathrm{Fe}_{2} \mathrm{O}_{3}, \mathrm{Fe}_{3} \mathrm{O}_{4}, \mathrm{FeCl}_{2}, \mathrm{FeCl}_{3}$, $\mathrm{FeF}_{2}, \mathrm{FeF}_{3}, \mathrm{FeS}, \mathrm{FeS}_{2}, \mathrm{FeSO}_{4}$ and $\mathrm{Fe}_{2}\left(\mathrm{SO}_{4}\right)_{3}$ [15]. Figure 7 showed that iron deficiency $(-\mathrm{Fe})$ inhibited the algal growth while iron enrichment $(+\mathrm{Fe})$ enhanced the phytoplankton productivity. However, fresh 100\% Japanese Ontake volcanic

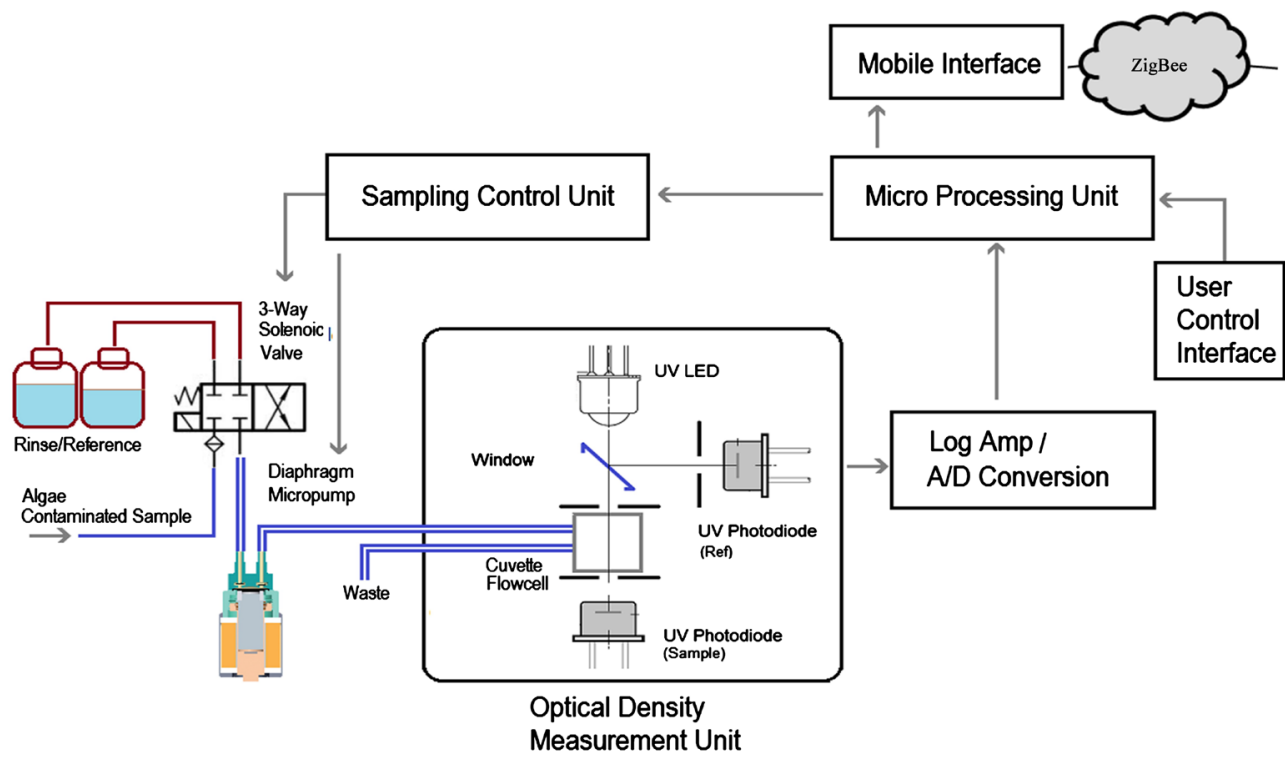

Figure 5. Schematic diagram for real-time monitoring system of Cochlonidium polykrikoides. 


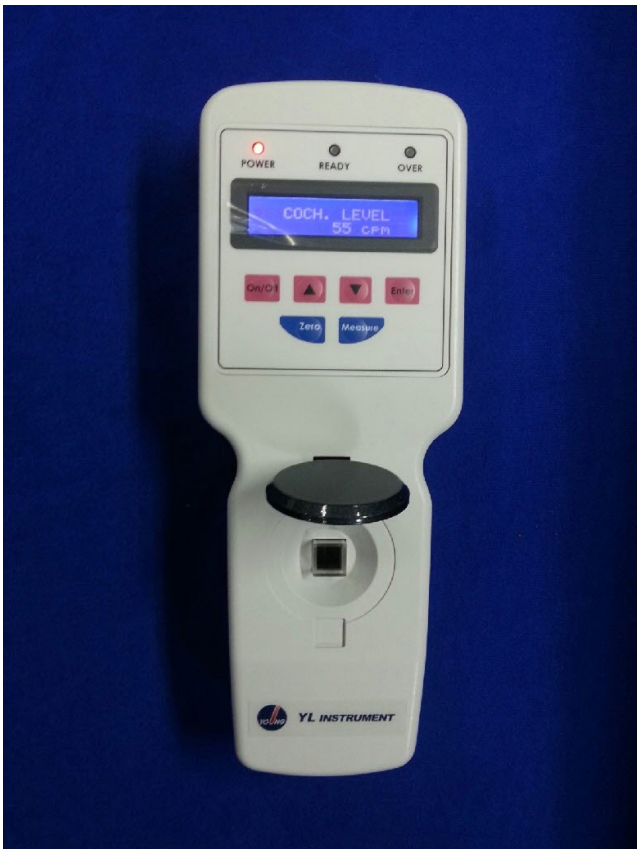

Figure 6. Proto-type detector with cuvette for concentration measurement of Cochlonidium polykrikoides at $300 \mathrm{~nm}$.

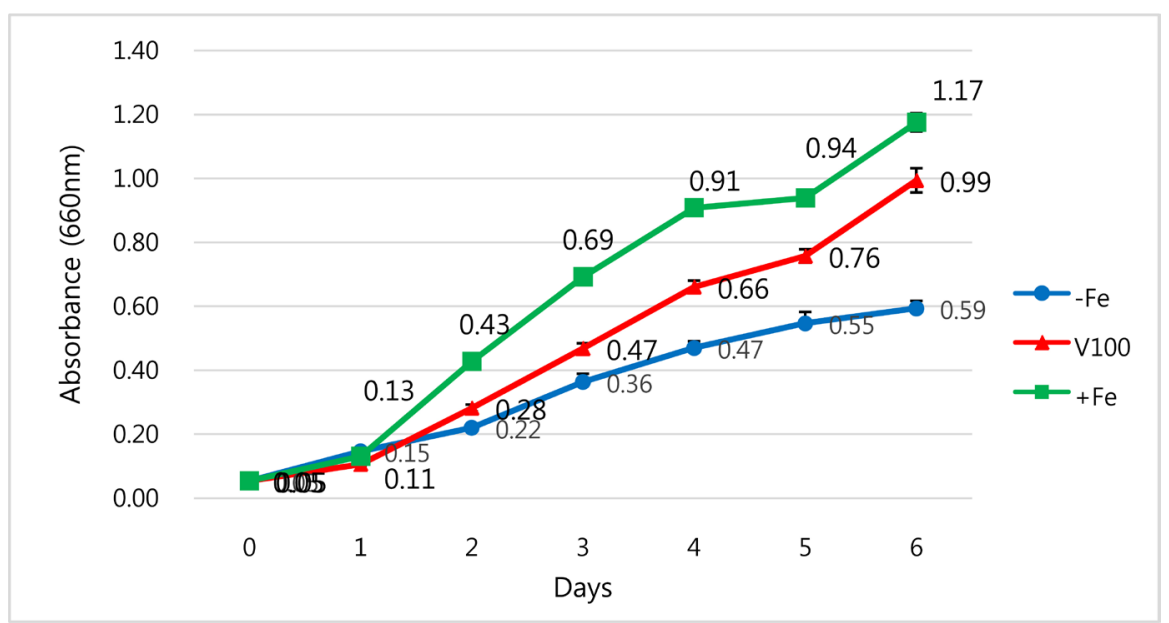

Figure 7. Growth curve of Chlorella vulgaris with various JM media; with its own Fe $(+\mathrm{Fe},-+-)$, fresh $100 \%$ volcanic ash $(\mathrm{V} 100,-\mathbf{\Delta}-)$, without its own $\mathrm{Fe}(\mathrm{Fe},-\bullet-)$.

ash with enriched sulfur compounds (V100) showed reduced algal growth.

There are sulfur compounds during volcanic eruptions either in the gas phase $\left(\mathrm{SO}_{2}, \mathrm{H}_{2} \mathrm{~S}\right)$ or liquid phase $\left(\mathrm{H}_{2} \mathrm{SO}_{4}, \mathrm{FeSO}_{4}\right.$ and $\left.\mathrm{Fe}_{2}\left(\mathrm{SO}_{4}\right)_{3}\right)$. Kim et al. [12] showed that sulfur compounds bind iron $(\mathrm{Fe})$ to sediment in black iron sulfides ( $\mathrm{FeS} / \mathrm{FeS}_{2}$ ) limiting the growth of phytoplankton. The more $\mathrm{SO}_{2}$ and $\mathrm{H}_{2} \mathrm{~S}$ available from either the volcanic gas or soluble sulfates, the more sedimentation occurs in the forms of FeS and $\mathrm{FeS}_{2}$. Therefore, it can be expected that the volcanic eruption enhances the formation of $\mathrm{FeS}$ and $\mathrm{FeS}_{2}$ making less $\mathrm{Fe}$ available to phytoplankton causing the Fe limited LC (Low-Chlorophyll) condition and ultimately less $\mathrm{HAB}$. 


\subsection{Sunlight and Cloth for Prevention of Cochlonidium polykrikoides}

Photosynthesis is the process by which sunlight energy is transformed into chemical energy to produce organic compounds that serve as cellular building blocks and energy reserves. In the first phase of the light dependent reactions, light energy that reaches the reaction center of chlorophyll-a molecules with the molecula formula of $\mathrm{C}_{55} \mathrm{H}_{68} \mathrm{O}_{5} \mathrm{~N}_{4} \mathrm{Mg}$, is stored in ATP and NADPH. The reverse reaction of photosynthesis is the cellular respiration, which occurs during the night for cells to obtain energy in ATP for maintenance of the cell and its growth [16].

Cochlonidium polykrikoides form several cells connected together for a larger surface area to get more solar energy during summer and early fall with a preference for the highest energy band at $300 \mathrm{~nm}$, as verified in Figure 4. Cochlonidium polykrikoides has a cylindrical diameter of $35 \mu \mathrm{m}$ and length of $25 \mu \mathrm{m}$ with several cells (8) connected together with surface area of $17,172 \mu \mathrm{m}^{2}$ (192,000 $\mu \mathrm{m}^{2}$ for eight cells) for blooming in summer and early fall. Therefore, any cloth around the fishery farm with pore diameter less than $35 \mu \mathrm{m}$ may block the penetration of Cochlonidium polykrikoides into the fishery farm. Since yellow light (577 - 597, $590 \mathrm{~nm}$ ) shows the least absorption (\%) of chlorophyll-a [17], artificial light with $590 \mathrm{~nm}$ can be installed in the fishery farm to repel Cochlonidium polykrikoides, normally requiring the highest solar energy at 300 nm (Figure 4).

Furthermore, $\mathrm{H}_{2} \mathrm{~S}$ from Biogas (solubility of 0.3 grams per $100 \mathrm{ml}$ water) was sprayed over the surface of seawater around outside of the fish cage to see the precipitation of algae without harming cage fish. It was thus proposed yellow LED at $590 \mathrm{~nm}$ be used as well as $\mathrm{H}_{2} \mathrm{~S}$ gas bubbling around the surface of the fish cage with a cloth of less pore diameter to protect the cage fish from the Cochlonidium polykrikoides.

\subsection{Path of Cochlonidium Polykrikoides}

Cochlonidium polykrikoides cultured in Indonesia should pass Banda Sea, Celebes Sea, and the South China Sea to reach Luzon Island. The Kuroshio Current carries Cochlonidium polykrikoides through major volcanoes (Bulusan, Kanlaon, Mayon, Taal, Pinatubo) and submarine volcanoes (Didicas, Camiguin de Babuyanes, Iraya, Pangasun, Babuyan Claro) in the Philippines. Since submarine volcanoes release sulfur compounds $\left(\mathrm{SO}_{2}, \mathrm{H}_{2} \mathrm{SO}_{4}\right.$, sulfate) and toxic chemicals $(\mathrm{HF}, \mathrm{HCl})$ directly into seawater with Cochlonidium polykrikoides, such a volcanic eruption can kill Cochlonidium polykrikoides. On the other hand, $\mathrm{SO}_{2}$ plume from a main volcano can deposit on the surface of seawater cause impact the death of Cochlonidium polykrikoides. Submarine volcanoes in seamounts induce earthquakes and volcanic eruptions above ground causing the low HAB in the seawater. It may be recommended to have a real-time monitoring system at 5 above-ground major volcanoes and 3 submarine major volcanoes in the 
Philippines. This would create an early warning system of HAB coordinating with the Philippines Institute of Volcanology and Seismology (PHIVOLCS). The lag time would be a maximal 1.5 months and minimal 0.5 months for the Kuroshio Current to reach the Korean coast. If there is a volcanic eruption from May to August in the Philippines, there can be a rare chance of HAB in Korea from July and August. Otherwise, there can be an outbreak of HAB in Korea during summer.

\subsection{El Niño and La Niña Events}

Submarine volcanoes are underwater vents or fissures in the Earth's surface from which magma can erupt, as shown in Figure 8.

Many submarine volcanoes are seamounts; typically extinct volcanoes that rise abruptly from a seafloor of 1000 - 4000 meters depth. The peaks are often found hundreds to thousands of meters below the surface, and are therefore considered to be within the deep sea. An estimated 30,000 seamounts occur across the globe [19].

The Ring of Fire in Figure 9 surrounds Indonesia (Java trench), Philippines (Philippine trench), and Japan (Ryukyu trench, Izu Ogasawara trench and Japan trench). Since the southern seashore of South Korea and the western seashore of Japan have no volcanic trenches, such locations can be good places for fish farming. However, the Kuroshio Current from the Philippines delivers Cochlonidium polykrikoides, suffocating fish and causing significant fishery damages every year from June to October in both South Korea and Japan.

\subsection{Volcanic Seamounts}

The planet's crust is broken into 17 major rigid tectonic plates while volcanoes and earthquakes are generally found in the plate boundaries at the bottom of the oceans. Therefore, most volcanic activity is submarine, as seen in deep sea

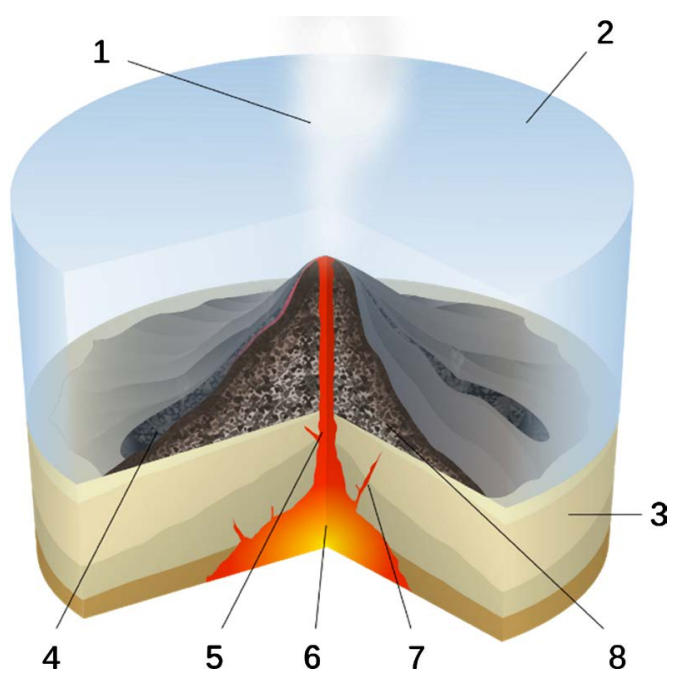

Figure 8. Scheme of a submarine eruption. 1. Water vapor cloud, 2. Water, 3. Stratum, 4. Lava flow, 5. Magma conduit, 6. Magma chamber, 7. Dike, 8. Pillow lava [18]. 


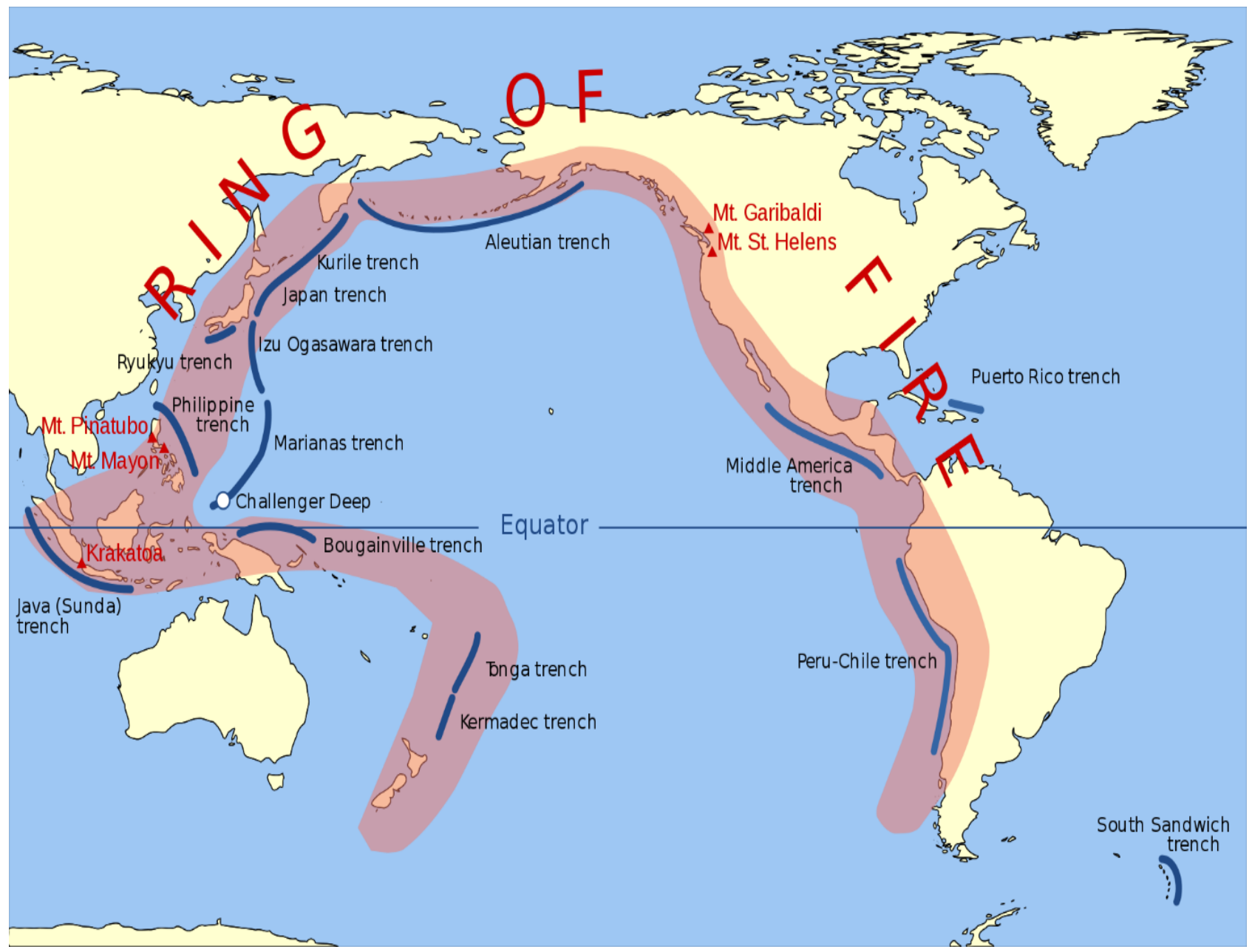

Figure 9. Ring of fire [20].

hydrothermal $\left(\geq 350^{\circ} \mathrm{C}\right)$ black smokers vents, releasing volcanic gases at the East Pacific Rise [21].

Extensive volcanic eruptions and earthquakes are caused by divergent, convergent and transform boundaries of tectonic plates [22]. Volcanic gases are commonly composed of $\mathrm{H}_{2} \mathrm{O}$ (37\% - 97.1\%), $\mathrm{CO}_{2}, \mathrm{SO}_{2}(0.50 \%-11.8 \%), \mathrm{H}_{2}, \mathrm{CO}$, $\mathrm{H}_{2} \mathrm{~S}(0.04 \%-0.68 \%), \mathrm{HCl}, \mathrm{HF}$. Toxic chemicals $\left(\mathrm{SO}_{2}, \mathrm{H}_{2} \mathrm{~S}, \mathrm{HCl}, \mathrm{HF}, \mathrm{H}_{2} \mathrm{SO}_{4}\right)$ from submarine and aboveground volcanoes have reduced the fishery productivity.

A critical parameter for the outbreak of HAB is the absence of volcanic eruptions in either Indonesia or the Philippines from May to June. Since the Kuroshio Current flows at 2 - 4 knots and the distance between Korea and the Philippines is $2628 \mathrm{~km}$, it may take 15 - 30 days.

Two weeks or a month are required for the Kuroshio Current to deliver Cochlonidium polykrikoides from Indonesia via the Philippines to the fishery farm in Korea. The absence of submarine volcanic eruptions can be possible if the seawater is cold during a La Niña event causing the outbreak of HAB resulting in with fishery damage in Korea. However, the aboveground volcanic erup- 
tions in Indonesia and the Philippines are in the Pacific Ring of Fire so volcanic eruptions can be caused by thermal energy being transferred from other countries in the Ring of Fire, as shown in Figure 9.

No red tides in 2018 were observed due to Mayon volcanic eruptions on March 8, 9, 10, 14, 23, May 24, June 18, July 1 while absence of red tide in 2017 could be caused by Canlaon volcanic eruptions (06/05/2017). There was extensive damage in 1995 (76.4 million USD damages), as shown in Table 2, since there were no volcanic eruptions in Bulusan, Taal, Mayon, and Canlaon in the Philippines. Besides, there were heavy rainfalls in July 1995 which induced Pinatubo's lahars from the eruption of 15 June 1991. This enhanced HAB as nutrient for Cochlonidium polykrikoides in the Philippines, were carried by the Kuroshio Current from the Philippines to Korea causing the largest fishery damage in Korea in 1995. In 2003, (21.5 million USD of damages) was due to early eruptions in Bulusan, Taal, Canlaon (17/3/2003) and Mayon (17/3/2003, 6/5/2003) before the summer in Korea.

The Mayon Volcano on Luzon Island in the Philippines erupted on January 18, 23, February 12, 26, March 9, 10, 14, 23, May 24, June 18, July 11, November 12, 14, 26 in 2018 and March 3, 2019. The Bulusan Volcano in Luzon erupted on January 2, 9, and March 1, 2018. Sulfur dioxide $\left(\mathrm{SO}_{2}\right)$ emissions were due to volcanic eruptions aboveground, as shown in Figure 10.

\subsection{Sunspot Number with El Niño and La Niña}

It is postulated that the maximal sunspot number with high solar radiation energy induces the warm Sea Surface Temperature (SST) during El Niño events while the minimal sunspot number with low solar radiation energy induces the cold SST during La Niña events [6], as schematically illustrated in Figure 11.

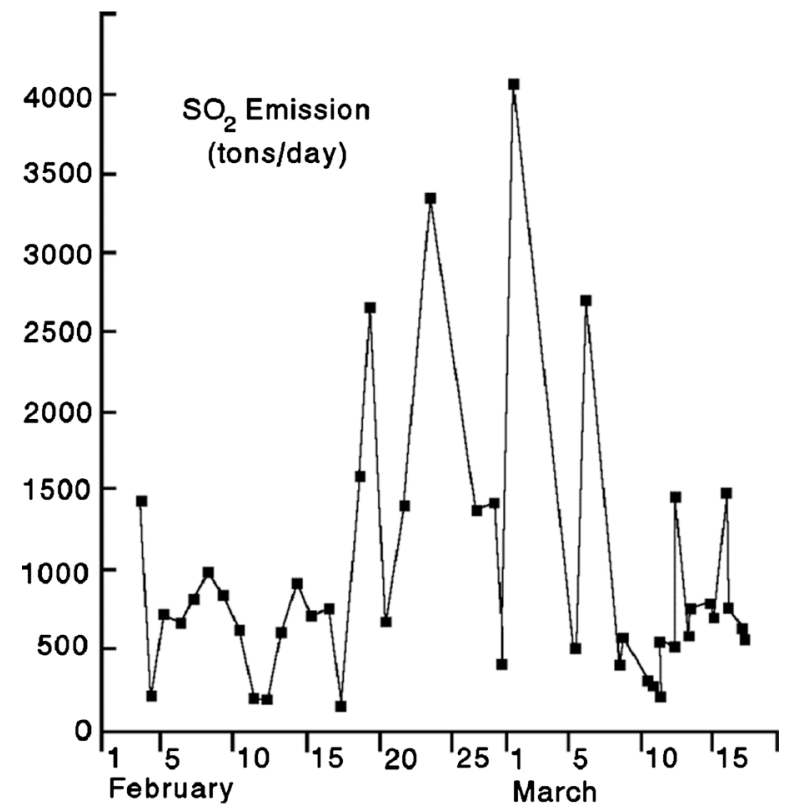

Figure 10. $\mathrm{SO}_{2}$ emission profile of Mayon volcano in the Philippines in 1993 [24]. 


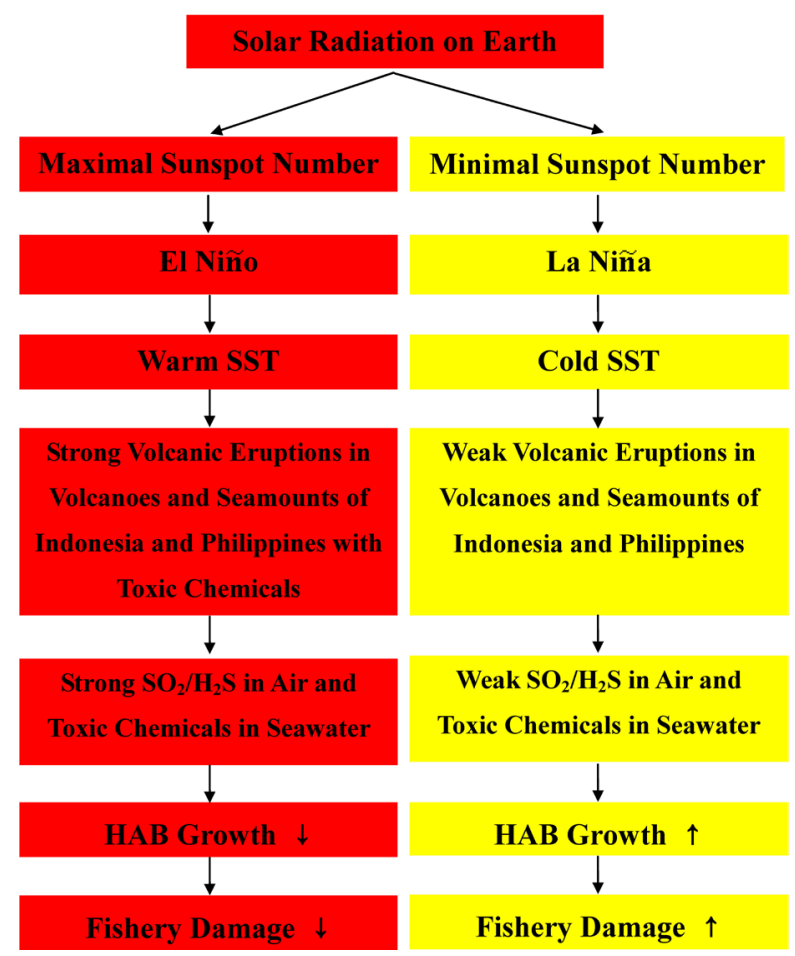

Figure 11. Sequential flow diagram of solar radiation on the Earth which induces El Niño events with the maximal sunspot number associated with strong volcanic eruptions in volcanoes and seamount in Indonesia and the Philippines for less fishery damage in Korea.

Solar radiation on Earth between 1870 and the present in terms of the average daily sunspot area [6] showed an 11-year cycle with a standard deviation of 14 months.

It is expected that there can be an outbreak of HAB causing high fishery damage during the minimal sunspot number with La Nina events resulting in weak volcanic eruptions in volcanoes and seamounts in Indonesia and the Philippines, as schematically illustrated in Figure 11.

Since 2019 is the period of the minimum sunspot number, there were HAB reading to 3.6 million USD of minor fishery damage. Such a small damage could be due to volcanic eruptions in Indonesia and the Philippines with detailed reasons as follows.

1) There was no heavy rainfall for washing out lahars,

2) There were volcanic eruptions from April (Indonesia) and May (Philippines) till August while major HAB in Korea from July to August,

3) During 2019, there were two volcanic eruptions only in Indonesia (Sinabung; May 7 and June 10, Tengger Caldera; February 18).

The distance between the Philippines and Korea is $1963 \mathrm{~km}$ and thus it takes 1.5 months for the Kuroshio Current $(0.5 \mathrm{~m} / \mathrm{s})$ to reach Korea with Cochlonidium polykrikoides cultured in Indonesia. If there is no volcanic eruption from the middle of May to the beginning of July in the Philippines, there can be HAB in Korea. The distance between Indonesia and Korea is $4322 \mathrm{~km}$ requiring 3.3 months to reach Korea. If there is no volcanic eruption from the $10^{\text {th }}$ of March to 
the $10^{\text {th }}$ of May in Indonesia, there can be HAB in Korea.

Table 1 implies that harmful algal blooms (HAB) occur during the minimal sunspot number, La Niña events, cold Sea Surface Temperatures (SST) during weak volcanic eruptions as well as in volcanoes and seamounts in Indonesia and Philippines. There has been HAB in South Korea during July, August and September (Figure 12) with heavy rainfall.

Fishery damage was plotted to the maximal concentration of Cochlonidium polykrikoides with full data of the maximal HAB concentration in Table 2, as shown in Figure 13. Figure 13 indicates fishery damage is linearly proportional $\left(R^{2}=0.7629\right)$ to the maximal concentration of HAB from 1993 to 2019. Figure 14 showed the minor linearity $\left(R^{2}=0.1446\right)$ between fishery damage and the sunspot number in Korea from 1993 to 2019. Figure 15 showed that fishery

Table 1. Sequential control parameters for fishery damage induced by harmful algal blooms in Korea.

\begin{tabular}{ccccccccc}
\hline $\begin{array}{c}\text { Sunspot } \\
\text { Number }\end{array}$ & Event & SST & $\begin{array}{c}\text { Volcanic } \\
\text { Indontions in } \\
\text { the Philippines }\end{array}$ & $\begin{array}{c}\text { Sulfur } \\
\left(\mathrm{SO}_{2,}\right. \\
\text { sulfate })\end{array}$ & $\begin{array}{c}\text { Toxic } \\
\text { Chemicals } \\
(\mathrm{HF}, \mathrm{HCl},\end{array}$ & $\begin{array}{c}\text { Iron } \\
(\mathrm{Fe})\end{array}$ & $\begin{array}{c}\text { Harmful } \\
\text { Algal } \\
\left.\mathrm{SO}_{4}, \mathrm{SO}_{2}\right)\end{array}$ & $\begin{array}{c}\text { Fishery } \\
\text { Damage }\end{array}$ \\
\hline High & El Niño & High & High & High & High & Low & Low & Low \\
Low & La Niña & Low & Low & Low & Low & High & High & High \\
\hline
\end{tabular}
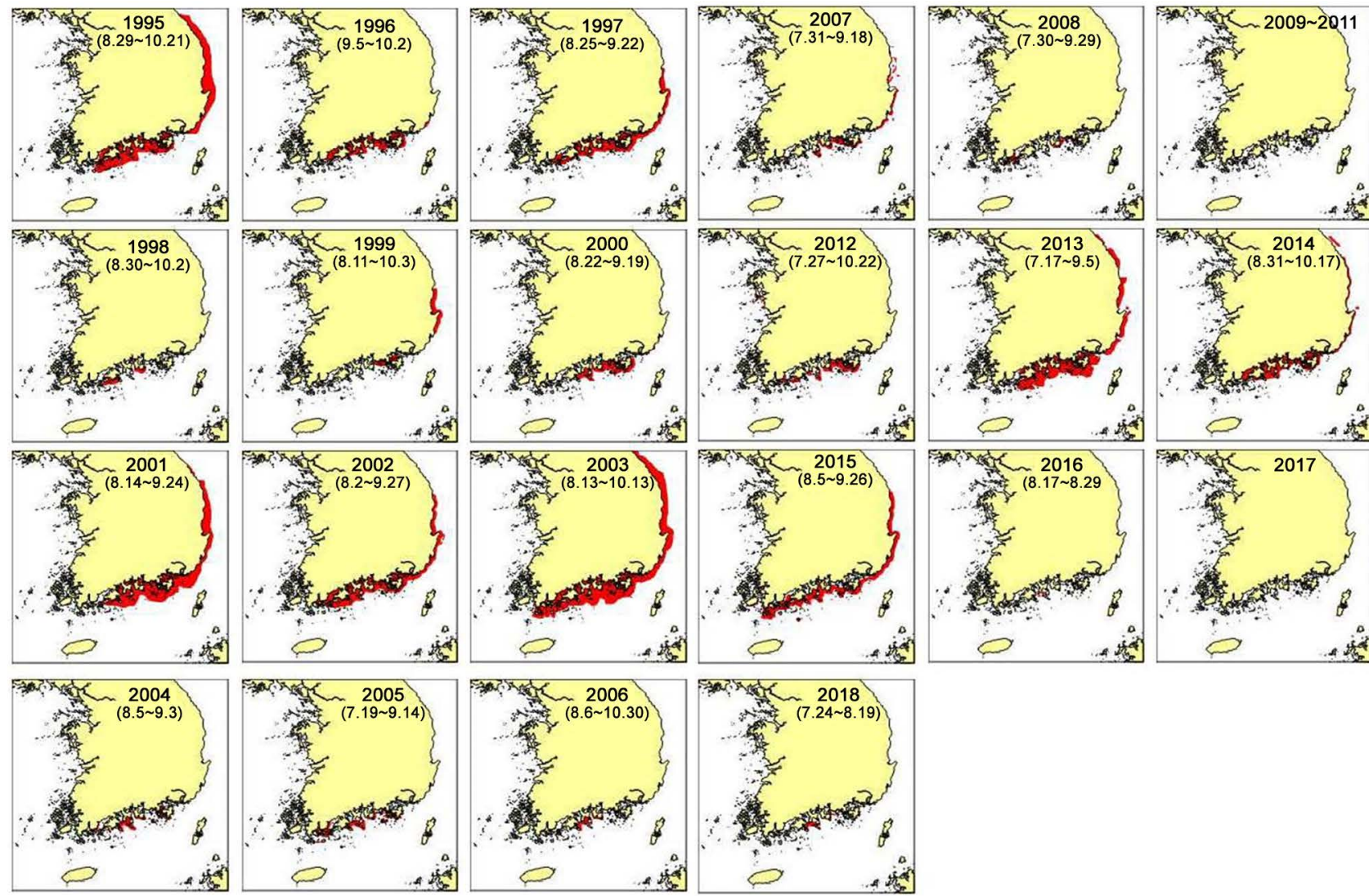

Figure 12. Yearly profile of harmful algal blooms along the Korean coast from 1995 to 2018 [23]. 
damage in South Korea from 1993 to 2019 was proportional $\left(\mathrm{R}^{2}=0.3413\right)$ to the La Niña Index, defined as +3 for the strong La Niña and -4 for the very strong El Niño [6].

Maximal sunspot number induces El Niño events, the latter being highly correlated $\left(\mathrm{R}^{2}=0.9939\right)$ with the year of volcanic eruptions in the Galapagos Hot Spot [6]. Strong volcanic eruptions produce sulfur dioxide $\left(\mathrm{SO}_{2}\right)$ and hydrogen sulfide $\left(\mathrm{H}_{2} \mathrm{~S}\right)$ plumes to take away iron from seawater in the form of iron sulfides in a low $\mathrm{HAB}$ region. On the other hand, the minimal sunspot number induces

Table 2. Fishery damage by Cochlonidium polykrikoides in South Korea from 1993 to 2019 with control parameters.

\begin{tabular}{|c|c|c|c|}
\hline Year & $\begin{array}{c}\text { Sunspot } \\
\text { Number [6] }\end{array}$ & $\begin{array}{c}\text { Event (El Niño; E, } \\
\text { /La Niña; L) (Figure 1) [6] }\end{array}$ & $\begin{array}{l}\text { Fishery Damage } \\
\text { (Million USD) [23] }\end{array}$ \\
\hline 1993 & 50 & E & 8.4 \\
\hline 1994 & 30 & $\mathrm{E}$ & 0.5 \\
\hline 1995 & 15 & $\mathrm{~L}$ & 76.4 \\
\hline 1996 & 10 & $\mathrm{~L}$ & 2.1 \\
\hline 1997 & 20 & E & 1.5 \\
\hline 1998 & 45 & E & 1.6 \\
\hline 1999 & 88 & $\mathrm{~L}$ & 3 \\
\hline 2000 & 125 & $\mathrm{~L}$ & 0.3 \\
\hline 2001 & 120 & $\mathrm{~L}$ & 8.4 \\
\hline 2002 & 100 & E & 4.9 \\
\hline 2003 & 60 & E & 21.5 \\
\hline 2004 & 35 & $\mathrm{E}$ & 0.1 \\
\hline 2005 & 25 & $\mathrm{E}$ & 1.1 \\
\hline 2006 & 20 & E & 0.1 \\
\hline 2007 & 5 & $\mathrm{~L}$ & 11.5 \\
\hline 2008 & 2 & $\mathrm{~L}$ & 0 \\
\hline 2009 & 1 & E & 0 \\
\hline 2010 & 10 & E & 0 \\
\hline 2011 & 30 & $\mathrm{~L}$ & 0 \\
\hline 2012 & 55 & $\mathrm{~L}$ & 4.4 \\
\hline 2013 & 62 & $\mathrm{~L}$ & 24.7 \\
\hline 2014 & 70 & $\mathrm{E}$ & 4 \\
\hline 2015 & 50 & $\mathrm{E}$ & 5.3 \\
\hline 2016 & 25 & $\mathrm{E}$ & 4.3 \\
\hline 2017 & 15 & $\mathrm{~L}$ & 0 \\
\hline 2018 & 5 & $\mathrm{~L}$ & 0.3 \\
\hline 2019 & 6 & $\mathrm{~L}$ & 3.6 \\
\hline
\end{tabular}




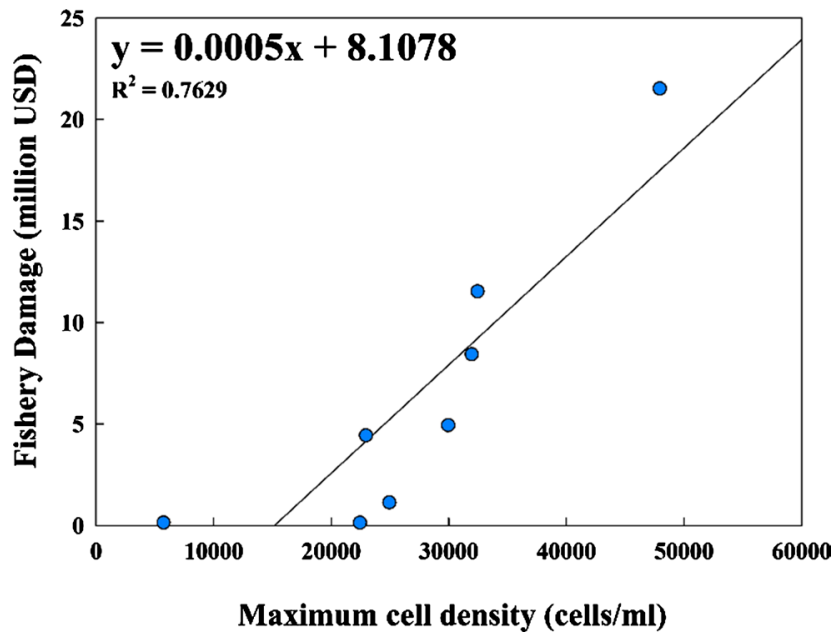

Figure 13. Fishery damage (USD) in linear relationship $\left(\mathrm{R}^{2}=0.7629\right)$ with the maximal concentration of red cell (cells/ml) from 1993 to 2019 in South Korea.

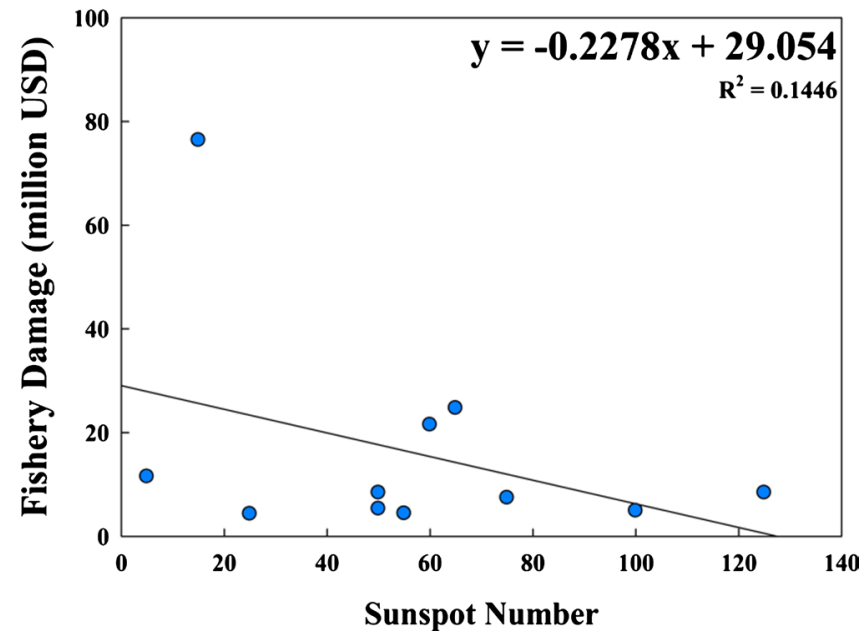

Figure 14. Fishery damage (million USD) in linear relationship $\left(\mathrm{R}^{2}=0.1446\right)$ with sunspot number in South Korea.

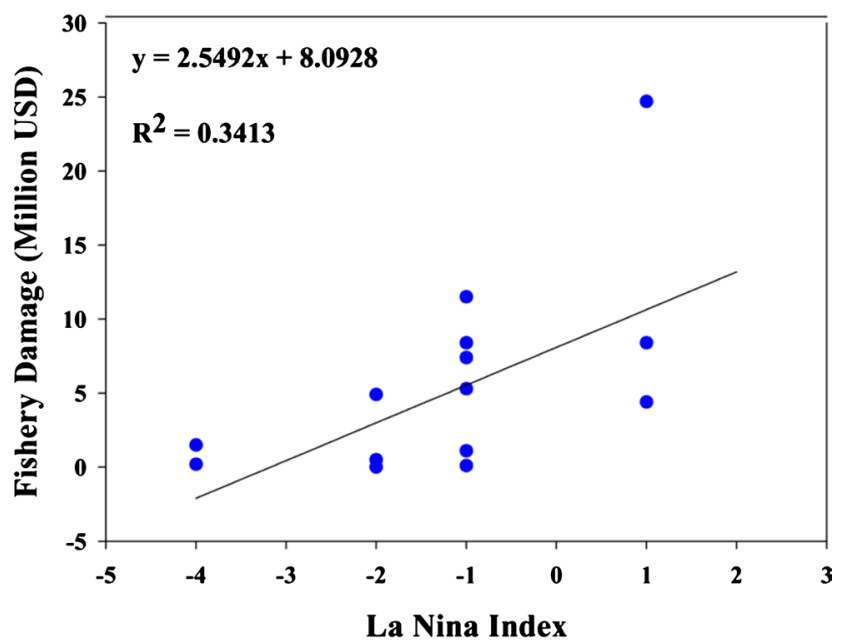

Figure 15 . Fishery damage was proportional $\left(R^{2}=0.3413\right)$ to the La Niña Index in South Korea. 
La Niña events, which result in less volcanic eruptions in Indonesia and the Philippines with consequent high HAB and fishery damage in Korea.

There are 23 volcanoes as active in the Philippines, 4 of which have frequent eruptions; Taal, Mayon, Bulusan, and Kanlaon, as shown in Table 1. Lahars have occurred during every rainy season since the eruption on 15 June 1991 at Mount Pinatubo of the Philippines. Pinatubo's last reported lahars were triggered by the heavy rainfalls of July 1995 which dissolved numerous minerals for $\mathrm{HAB}$ and induced the largest fishery damage in Korea in 1995.

Fishery damage was reversely proportional to the number of sunspots; the maximal number of sunspots induced frequent volcanic eruption in Indonesia and the Philippines for retardation of $\mathrm{HAB}$ with less fishery damage in Korea while the minimal number of sunspots caused less volcanic eruptions for thereby enhancing $\mathrm{HAB}$ resulting in more fishery damage.

Pinatubo volcanic eruption in June 1991 produced volcanic ash fallout in the South China Sea, as shown in Figure 16. Pinatubo's last reported lahars were triggered by the heavy rainfalls of July 1995 , when $30 \times 10^{6} \mathrm{~m}^{3}$ of debris, deposited over a $12 \mathrm{~km}^{2}$ area, enhanced $\mathrm{HAB}$ as nutrients, causing the largest fishery damage in Korea in 1995.

Measurements of sulfur dioxide emissions in Figure 10 showed a rapid increase from $500 \mathrm{t}$ (550 short tons) per day from May 13 to $5000 \mathrm{t}$ (5500 short tons) per day from May 28 in 1991.

The eruption produced hot ash and gas, massive lahar floods and huge clouds of superheated volcanic material hundreds of kilometers across. There was lahar triggering rainfall in July of 1995 when extensive HAB occurred in Korea, as shown in Table 2.

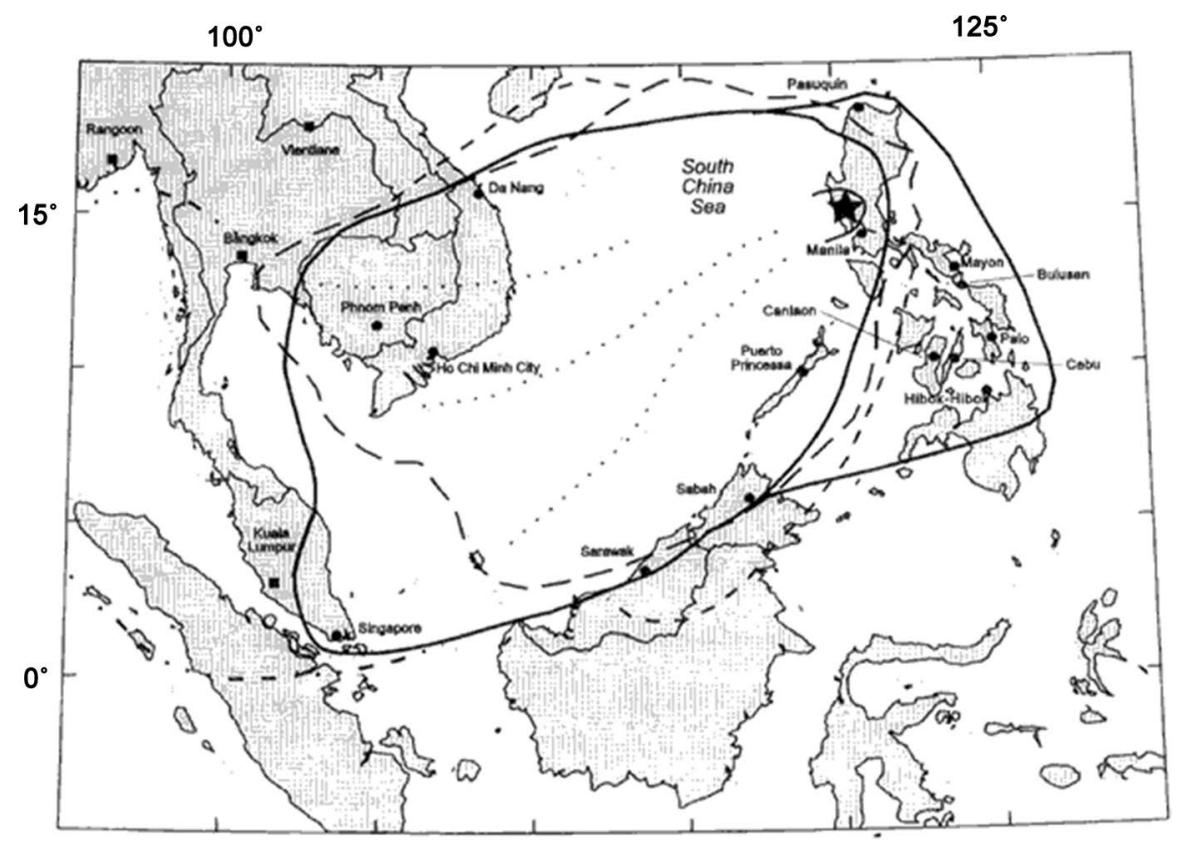

Figure 16. The location of Mount Pinatubo and the regional ash fallout from the 1991 eruption [24]. 


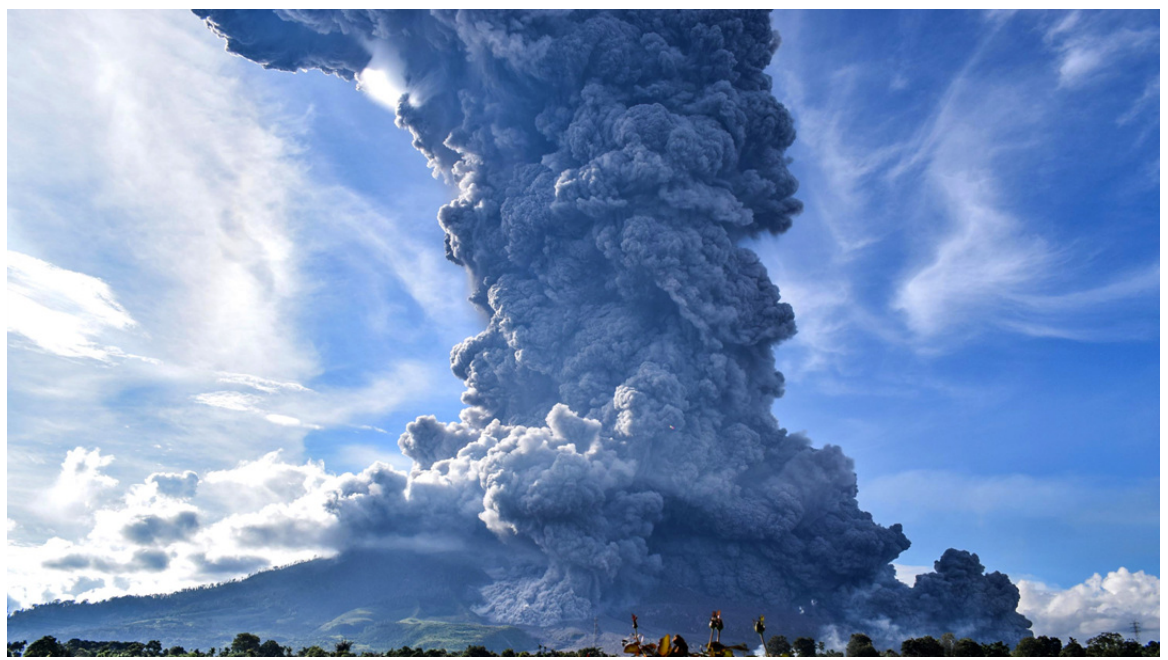

Figure 17. Volcanic eruption of Sinabung volcano in Indonesia on June 10 of 2019.

Since $\mathrm{HAB}$ reaches its peak point during the summer months of July to August with high precipitation for nutrient supply from the land, no occurrence of $\mathrm{HAB}$ can be expected if there are volcanic eruptions in the Philippines during May, June, July, and August accounting for one month of culture and one month of delivery to the Korean coast.

Even though the year of 2019 was the phase of the minimal sunspot number during La Niña event, there were major volcanic eruptions in Mount Sinabung in Indonesia, as shown in Figure 17 to induce a negligible HAB without high fishery damages in 2019 (3.6 million USD).

\section{Conclusions}

Harmful Algal Blooms (HAB) were analyzed to trace the outbreak of dinoflagellate Cochlonidium polykrikoides on the Korean coast from 1993 to 2019. Parameters associated with blooms and fishery damage were sunspot number, El Niño/La Niña events, Kuroshio Current and volcanic eruptions in the South China Sea including Indonesia and the Philippines. HAB development was halted in seawater due to the sulfur compounds $\left(\mathrm{H}_{2} \mathrm{~S}, \mathrm{SO}_{2}\right.$, sulfates) from volcanic eruptions inducing the deficiency of the dissolved iron $(\mathrm{Fe})$ in seawater from June to October. Cochlonidium polykrikoides blooms could be predicted by the minimal sunspot number during La Niña event or weak volcanic eruptions in Indonesia and Philippines. On line monitoring of HAB was suggested using a prototype detector of Cochlonidium polykrikoides at a wavelength of $300 \mathrm{~nm}$ with the concentration linearity $\left(\mathrm{R}^{2}=0.9972\right)$ between 1000 and 6000 cells/ml. HABs on the Korean coast were negligible when there were volcanic eruptions in either Indonesia or the Philippines from May to August. Fishery damage was linearly proportional $\left(\mathrm{R}^{2}=0.7629\right)$ to the maximal concentration of HAB. Fishery damage was reversely proportional to the number of sunspots; the maximal number of sunspots induced frequent volcanic eruption in Indonesia and the Philippines for retardation of $\mathrm{HAB}$ with less fishery damage in Korea 
while the minimal number of sunspots caused less volcanic eruptions for thereby enhancing $\mathrm{HAB}$ resulting in more fishery damage.

It was proposed that a yellow LED be used at $590 \mathrm{~nm}$ as a photochemical expellent as well as $\mathrm{H}_{2} \mathrm{~S}$ gas bubbling at a 0.5 meter depth on the surface of the fish cage to inactivate chemically Cochlonidium polykrikoides due to the deficiency of essential iron in the seawater. In addition, the physical method of blanketing the cage cloth with smaller pore diameter than that of HAB was used for prevention of Cochlonidium polykrikoides penetrating into the fish cage.

\section{Acknowledgements}

The author appreciates the assistances by the colleagues such as Dr. Y. S. Seo (National Institute of Fisheries Sciences) in the data of Cochlonidium polykrikoides, Dr. Dae Geun Kim (Department of Bioprocess Engineering, Chonbuk National University) for the data in batch culture of Chlorella Vulgaris, and Young in Scientific for assisting the manufacture of the proto-type detector of Cochlonidium polykrikoides. This work was funded by The University of Suwon and G-Land, Republic of Korea. Editing work undertaken by Professor Jonathan Wright is also greatly appreciated.

\section{Conflicts of Interest}

The author declares no conflicts of interest regarding the publication of this paper.

\section{References}

[1] Granēli, E. and Turner, J.T. (2006) Ecology of Harmful Algae, 1893. Springer, Berlin. https://doi.org/10.1007/978-3-540-32210-8

[2] Resnick, B. (2018) Why Florida's Red Tide Is Killing Fish, Manatees, and Turtles, Vox.

[3] Edvardsen, B. and Imai, I. (2006) The Ecology of Harmful Flagellates within Prymnesiophyceae and Raphidophyceae. In: Granēli, E. and Turner, J.T., Eds., Ecology of Harmful Algae, Springer, Berlin, 67-79. https://doi.org/10.1007/978-3-540-32210-8_6

[4] Kim, T.J., Jeong, J.C., Seo, R.B., Kim, H.M., Kim, D.G., Chun, Y.S., Park, S.U., Yi, S.H., Park, J.J., Lee, J.H., Lee, J.J. and Lee, E.J. (2014) An Initiative Study on Relationship between Algal Blooms and Asian Dust for Regulation of Algal Blooms. Korean Society for Biotechnology and Bioengineering Journal, 29, 285-296. https://doi.org/10.7841/ksbbj.2014.29.4.285

[5] Kim, T.J. (2018) Prevention of Harmful Algal Blooms by Control of Growth Parameters. Advances in Bioscience and Biotechnology, 9, 613-648.

https://doi.org/10.4236/abb.2018.911043

[6] Kim, T.J. (2019) El Niêño, La Niña and Record Low Chicago Temperature by Sunspot Number. Natural Science. (In Press)

[7] Mancero, J. (2017) Climate Change and Galapagos. GalapagosIslands.com.

[8] Jeong, H.J., et al. (2017) Ichthyotoxic Cochlonidium polykrikoides Red Tides off Shore in the South Sea, Korea in 2014: I. Temporal Variations in Three-Dimensional Dis- 
tributions of Red Tide Organisms and Environmental Factors. Algal, 32, 101-130. https://doi.org/10.4490/algae.2017.32.5.30

[9] Iwataki, M., Kawami, H., Matsuoka, K., Omura, T. and Fukuyo, Y. (2005) Phylogeny and Geographtical Distribution of Cochlonidium polykrikoides Population Collected from Annual Report 2005. PICES 14th Annual Meeting, Vladivostok, 29 September-9 October 2005.

[10] Na, G.H., et al. (1997) Diel Migration of Dinoflagellates, Cochlonidium polykrikoides in Situ. Journal of Aquaculture, 10, 457-462.

[11] https://geography.name/kuroshio-current

[12] Suh, Y.S., Jang, L.H., Lee, N.K. and Ishizaka, J. (2004) Feasibility of Red Tide Detaction around Korean Waters Using Satellite Remote Sensing. Journal of Fisheries Science and Technology, 7, 148-162. https://doi.org/10.5657/fas.2004.7.3.148

[13] Kim, T.J., Hong, G.H., Kim, D.G. and Baskaran, M. (2018) Iron Fertilization with Enhanced Phytoplankton Productivity under Minimal Sulfur Compounds and Grazing Control Analysis in HNLC Region. American Journal of Climate Change, 8, 14-39. https://doi.org/10.4236/ajcc.2019.81002

[14] Schrope, M. (2008) Oceanography: Red Tide Rising. Nature, 452, 24-26. https://doi.org/10.1038/452024a

[15] United States Geological Survey (2011) Volcano Hazards Program. 22.

[16] Duggen, S., Olagun, N., Croot, P., Hoffmann, L., Dietze, H., Delmelle, P. and Teschner, C. (2010) The Role of Airborne Volcanic Ash for the Surface Ocean Biogeochemical Iron-Cycle: A Review. Biogeosciences, 7, 827-844. https://doi.org/10.5194/bg-7-827-2010

[17] Maher, B.A., Prospero, J.M., Mackie, D., Gaiero, D., Hesse, P.P. and Balkanski, Y. (2010) Global Connections between Aeolian Dust, Climate and Ocean Biogeochemistry at the Present Day and at the Last Glacial Maximum. Earth-Science Reviews, 99, 61-97. https://doi.org/10.1016/j.earscirev.2009.12.001

[18] https://en.wikipedia.org/wiki/Submarine_eruption

[19] https://en.wikipedia.org/wiki/Submarine_volcano

[20] Klemetti, E. (2018) No, the "Ring of Fire" Is Not a Real Thing. Discover, January 26.

[21] Fornari, D., Tivey, M., Schouten, H., Perfit, M., Yoerger, D., Bradley, A., Edwards, M., Haymon, R., Scheirer, D., Damm, K.V., Shank, T. and Soule, A. (2004) Submarine Lava Flow Emplacement at the East Pacific Rise $9^{\circ} 50^{\prime} \mathrm{N}$ : Implications for Uppermost Ocean Crust Stratigraphy and Hydrothermal Fluid Circulation. Geophysical Monography, 148, 187-218. https://doi.org/10.1029/148GM08

[22] Plafker, G. (1965) Tectonic Deformation Associated with the 1964 Alaska Earthquake. Science, 148, 1675-1687. https://doi.org/10.1126/science.148.3678.1675

[23] Ministry of Korean Marine Fishery (2019) General Response to Red Tide Outbreak in 2019.

[24] Mount Pinatubo, Wikipedia. 